\section{The Digital Divide, the UN, and the Computing Profession}

Neville Holmes, University of Tasmania
This line-up makes it no surprise that the draft declaration embodies a bizarre farrago of largely ideological and often contradictory platitudes. The draft action plan isn't much better. Thus, I consider it highly unlikely that the outcome of this UN summit will be any more effective than the outcome of recent World Trade Organization meetings.

\section{THE PROFESSIONAL APPROACH}

The UNICTTF list's most significant feature, however, is the complete absence of professional bodies of any kind. Perhaps this absence stems from professional organizations' disinclination to either take part in an apparent boondoggle or to appear to support the most likely outcome of such an event.

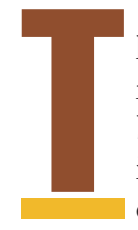

he term digital divide usually refers to the great disparities between and within societies in the use of digital technology. This month, the United Nations is holding a World Summit on the Information Society (WSIS: www. itu.int/wsis/index.html) to adopt a declaration that embodies, in its draft form at least, "the ambitious vision" of "bridging the Digital Divide." The declaration's hopes focus on

\begin{abstract}
the rapid pace of development of ICTs [information and communication technologies]—unprecedented in history-which allows for the development of applications that make it possible that no one is left behind and that those who were left marginalised in previous development cycles can have a real opportunity to attain higher levels of development without having to follow the traditional path nor its time requirements.
\end{abstract}

\section{THE COMPUTING PROFESSION}

We might think that a UN summit focused on the application of digital technology would enjoy the participation of professional bodies, particularly those representing engineers and computing professionals. The list of "enti-

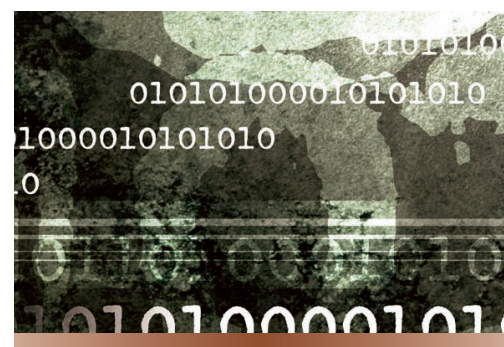

The world needs the computing profession, but do the politicians want us?

ties involved" does include the International Federation for Information Processing and the International Institute for Applied Systems Analysis. But, considering that the list contains more than 2,000 entities of bewildering variety, the participation of engineers and computing professionals seems purely nominal.

More significant is the shorter list of the partner organizations of the United Nations Information and Communication Technologies Task Force, the main-or at least professionally most relevant-body behind the summit (www.unicttaskforce.org). My classification of these organizations yields 15 political bodies, divided into eight UN and seven national government bodies; 13 commercial bodies, of which eight are corporations like Cisco and Hewlett Packard; and seven or eight miscellaneous minor organizations.
Whatever the reason, their absence is deplorable. Professional people, dissociated from business and politics, are best qualified to thump the table, insist on purposeful and effective approaches to solving problems, inform the decision makers of the nature and significance of technical realities, and advise them of different solutions' relative feasibility and benefits.

When solving problems professionally, we must first define each problem's scope and nature. The "ambitious vision" makes it clear that the people behind WSIS take the problem to be the digital divide. A moment's informed thought should confirm that the digital divide represents only one symptom of the chasms that increasingly divide rich nations from poor and the rich within nations from their poor, as the United Nations Development Continued on page 142 
Programme has long persistently and fruitlessly documented (www.undp. org).

The draft declaration states, "We are aware that technology alone cannot solve any political and social problems. ICTs should therefore be regarded as a tool and not an end in themselves." But the declaration shows no awareness that the basic problem's severity might spring at least partly from the use of digital technologies, or even that digital technologies might be completely irrelevant in many circumstances-as they must be, for example, to the 24,000 people who die of hunger daily (www. thehungersite.com).

Another principle of problem solving dictates that we understand the problem's causes. In understanding gross social inequity, a system analyst's skills become relevant. One common economic argument denies the existence of the problem on the grounds that per capita gross domestic product or average annual income is increasing everywhere. This may be true. But a system analyst could point out that

- the subjective inequity is in wealth, not productivity or income;

- the ability to acquire wealth in a monetary society depends on an excess of income over living costs;

- wealth once acquired accelerates its own growth; and

- this results in a dumbbell effectthe wealthy naturally get wealthier while the poor get relatively poorer.

Once defined, a problem must be placed in its full context. The UN WSIS declaration repeatedly places overriding importance on increased economic development. Yet we have reason to doubt that global conditions will let us sustain present levels of economic production much longer, much less support increased production levels (www. guardian.co.uk/Print/0,3858,4782372, 00.html).

\section{DIGITAL TECHNOLOGY}

When tackling the problem of sustained economic production, we canwhether we agree with him or notconsider eminent capitalist George Soros' views on the global capitalist system's deficiencies (www.theatlantic. com/issues/98jan/opensoc.htm). Soros puts these deficiencies into five classes, thereby providing an analytical structure for examining the close links between digital technology and global capitalism:

\section{In understanding gross social inequity, a system analyst's skills become relevant.}

- The benefits of global capitalism are unevenly distributed. Digital technology makes capital and profits much more mobile than labor and goods, providing perhaps the most important of those factors that "combine to attract capital to the financial center [of the global economy] and account for the ever increasing size and importance of financial markets."

- Financial markets are inherently unstable, and international financial markets are especially so. Soros makes many comments regarding market equilibrium and economic theory. But apart from this, we should note that digital technology has both enabled the formation of a global financial system more complex than the national ones it replaced and greatly reduced the system's reaction time to disturbances. Complex systems with small time constants are inherently less stable, as the recent catastrophic failures of integrated electricity distribution systems-such as those that have repeatedly blacked out much of northeast North Americashow.

- Instability is not confined to the financial system, however. The goal of competitors is to prevail, not to preserve competition in the market. Digital technology provides an effective tool for avid competitors. Successful companies typically become more successful by reducing their costs, and large companies are much more able than small companies to reduce costs by exploiting digital technology. If it's only stability we're after, monopolies or oligopolies might be the best result, except that some think they make a much bigger mess when they do eventually crash.

- Since the end of the Second World War the state has played an increasing role in maintaining economic stability, striving to ensure equality of opportunity, and providing a social safety net, particularly in the highly industrialized countries of Europe and North America. But the capacity of the state to look after the welfare of its citizens has been severely impaired by the globalization of the capitalist system. Digital technology has made global private enterprises spectacularly successful. Yet corporations and a few private citizens in developed countries own or control most of these enterprises, exerting an influence so profound that governments and major political parties have wholeheartedly adopted an economy-first approach to policy and legislation. This is particularly noticeable here in Australia.

- Every society needs some shared values to hold it together. Market values on their own cannot serve that purpose... We can have a market economy but we cannot have a market society. This Soros considers to be "the most nebulous problem area." His concern is also the most relevant to WSIS, given that the IS in WSIS stands for information society-the area in which digital technology has most significance. 
Readers who assume Soros argues for abandoning capitalism will be mistaken and should consult the cited paper or www.soros.org.

\section{THE INFORMATION SOCIETY}

The WSIS draft declaration's unbridled enthusiasm for the information society depicts it as a new kind of paradise. The computing profession could give this view a more realistic perspective.

Human societies and primates in general have always formed information societies, as delightfully displayed in the last two episodes of David Attenborough's The Life of Mammals. Recent digital technologies have given us extremely cheap machines for generating, displaying, storing, and transmitting data: representations of the ideas that in the human mind can become information. New, at least in their intensity, are the industries that have arisen to exploit data commercially.

The very cheapness of modern machinery would ordinarily ensure plenty of competition for data-based industries, but global corporations use patent and copyright monopolies to hamper if not completely suppress competition. They also use digital technologies to enforce their monopolies. Indeed, the World Intellectual Property Organization, a UNICTTF partner, "is dedicated to promoting the use and protection of ... intellectual property" (www.unicttaskforce.org/stakeholders/ partnerships/partnerships_txt.asp).

Thus, when the UN declaration affirms that "In building such an information society, the ability for all to access and contribute their information, ideas and knowledge is essential," this sentiment seems platitudinous indeed in the face of commercial reality. Most disturbingly, this passage and the declaration as a whole give the impression that the world should aim to create a single, uniform, information society by using digital technology to bring the developed world's benefits to "those who were left marginalised in previous devel- opment cycles." Two assumptions underpin this statement:

- societies in the developed world have benefited from technological development, and

- what will benefit the developed world will ipso facto benefit the undeveloped world.

We can doubt from a social viewpoint the net benefits of technology, considering the gross social inequities that have developed in the so-called advanced countries since digital technology's widespread adoption. Certainly, we can reasonably doubt that digital technology should be used in the Third World in the same way it has been used in the First World.

\section{Global corporations use digital technologies to enforce their monopolies.}

The UN declaration properly emphasizes education. Unfortunately, it also implies that the First World's educational system should be brought to the poor world and that digital technology will play a central role in delivering it.

This brings us back to Soros' fifth problem - the shared values that a successful society must have. Education provides the means for maintaining traditional shared values; thus, the family and professional educators, not digital technology, provide education's essential and principal tools. The educational system's failure to maintain traditional social values in a world where, frequently, no family exists to perform that role, provides the most likely reason for the First World's social gaps.

In this vacuum, marketeers choose social values and use media such as television, video games, and, increasingly, the Internet and its Web (www. nybooks.com/articles/16746) to instill them. In response, innumeracy and illiteracy increase steadily while inoralcy-the inability to communicate orally-has become a problem in primary schools (news.bbc.co.uk/2/hi/ uk_news/education/3239861.stm).

A lthough I believe the WSIS is doomed to failure, it forms only part of an effort scheduled to go on until at least 2005. This work offers all professionals, and particularly computing professionals, an opportunity to urge their representative bodies to press for a formal role in the WSIS sequels and similarly important international endeavors.

Professionals who can do so should volunteer to support their professional bodies and other organizations in any activities that seek to better both their own and international society. Digital technology has a great potential for supporting such efforts. The difficulty lies in realizing that potential.

Neville Holmes is an honorary research associate in the School of Computing on the Launceston campus of the University of Tasmania. Contact himat neville.holmes@utas.edu.au. Details of the citations in this essay, and links to further material, are at www.comp.utas.edu.aulusers/nholmes |prfsn/.

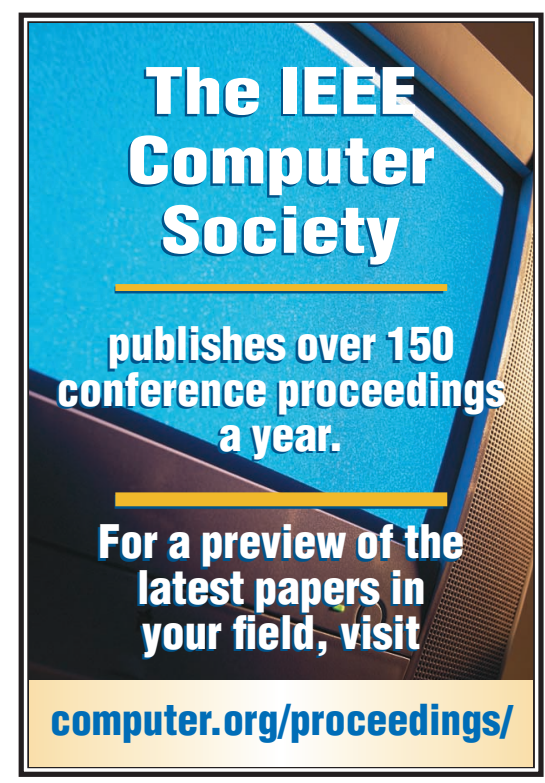

